\title{
Other Epidemiology and Cancer Control Shared Resource
}

National Cancer Institute

\section{Source}

National Cancer Institute. Other Epidemiology and Cancer Control Shared Resource. NCI

Thesaurus. Code C39486.

Other Epidemiology and Cancer Control Shared Resource provides services not provided by resources listed above. 